\title{
Web-based Seminar - New Source of Qualitative Study: Data Collection during the Pandemic of COVID-19
}

\author{
Wen Ni Tiong ${ }^{1 *}$, Anne Freda Sim Siaw Fen ${ }^{2}$ \\ ${ }^{1}$ Institute for Globally Distributed Open Research and Education (IGDORE), Malaysia \\ 2 University of Sunderland, Faculty of Business \& Law, United Kingdom \\ * Corresponding author: wenni.tiong@igdore.org
}

Article History

Received 2020-10-12

Revised 2020-11-11

Accepted 2020-11-12

Published 2020-11-18

\section{Keywords}

Web based Seminar

Qualitative data

COVID 19

Technology adoption

How to cite?

Tiong, W. N., \& Sim, A. F. S. F. (2020). Web-based Seminar - New Source of Qualitative Data: Data Collection during the Pandemic of COVID-19. SEISENSE Journal of Management, 3(6), 50-64. doi:

$10.33215 /$ sjom.v3i6.477
Abstract

Objective- This article aims to discuss the authors' own experience using a web-based seminar (webinar) as a new data collection method for a qualitative descriptive study on factors influencing digital banking adoption among potential users in Malaysia (Digital Banking Study).

Design - This will be the first study to gather information from industry players and public perception towards digital banking service using webinars, with evidence compared to the study's quantitative results.

Findings - Data derived from webinar sessions are consistent with the quantitative results, and the potential of its uses as a new research tool was discussed in detail. Policy Implications- The findings showed several practical implications that are potentially useful for researchers, academics, and business analysts to consider adopting webinar data as a new qualitative data collection method.

Originality - This study documents the supporting evidence of the potential use of webinars as a useful tool to collect quality observation data. 


\section{Introduction}

World Health Organization (WHO) declared the COVID-19 pandemic in March 2020, a global outbreak caused by the alarming and perilous spread of the COVID-19 virus (World Health Organization, 2020). The rising international cases, including Malaysia, have imposed strict lockdown to curb the virus's spread. The Malaysian government has implemented cordon sanitaire, also known as Movement Control Order, as a preventive action in response to the COVID-19 pandemic on 18 March 2020. This order encompasses restrictions and sanctions on all inbound and outbound travels, the general prohibition of mass gatherings nationwide, closure of all public and private educational institutions, as well as all government and private organizations except those affiliated in essential services. These essential services include healthcare, banking, telecommunications, irrigation, energy, oil, gas, pharmacy, safety, food supply, postal, broadcasting, port, and amenities (Prime Minister's Office of Malaysia, 2020). This lockdown has made significant disruptions across various industries, primarily, where the halt of global travel has resulted in the drastic decline of international trade and economic performances, fallen shares, interruption in the supply chain, production and manufacturing, human resource management, job losses, bankruptcies, as well as social ramifications (Carnevale \& Hatak, 2020). Additionally, it has also affected academic activities with the closure of schools and educational institutions and has dramatically challenged the education sector, including the students, parents, and educators (Kapasia et al., 2020).

When the pandemic hit in the early year 2020, the obstacles of collecting sufficient and quality data have inspired us to seek other alternative other than the traditional way to collect more research data. 'The Digital Banking Study" study was proposed in the beginning of pandemic to investigate the factors influencing user behavior to adopt digital banking services in Malaysia through the integration of the extended technology adoption model (TAM) and innovation diffusion theory (IDT). TAM, developed from the Theory of Reasoned Action (TRA), incorporates the perspective of behavioral science into perceived usefulness and perceived ease of use is one of the most widely used models in the field of information technology adoption research (Davis, 1986; Venkatesh \& Bala, 2008; Zhang, 2018). However, despite its widespread use, TAM is insufficient to explain voluntary user acceptance of new technology in mobile banking (Xiong, 2013). To let us see more aspects of the possible factors that could influence the adoption of digital banking services, it is also important to understand the role of innovation in adopting adoption. The rate of adoption of an information technology product or service can be defined as "the relative speed with which members of a social system adopt an innovation" (Rogers, 1995). The digital banking services is currently in its infantry stage in Malaysia, thus motivates us to explore the individual adoption behavior from multiple aspects through the integration of TAM and IDT theories.

To obtain diverse opinions and comments from the industry players, the Digital Banking Study emphasizes the uses of triangulation methods by incorporating quantitative and qualitative data functions. As an extension of the Digital Banking Study, this paper focuses on the experts' opinion on their perception of the challenges, opportunities, and consumers' acceptance of digital banking services to establish vigorous discussion and interpretation of empirical analysis findings. Therefore, Digital Banking Study proposed using web-seminar (webinar) as a new data collection source to avoid disruption of obtaining quality research data even during a pandemic. This method is aligned with the global education establishments' demand to innovate and adapt to new learning methods in a short timeframe by United Nations as the pandemic continues (United Nations, 2020). These approaches include embracing digital technology either through online services or informationsharing platforms like Zoom, which has globalized connectivity (Donthu \& Gustafsson, 2020). Additionally, the potential use of digital technologies as tools to meet the new standard practice in businesses and healthcare operations have also been studied (Papadopoulos et al., 2020; Webster, 2020).

Although the global trend of digitalization has transformed how education is designed, delivered, and implemented, there is a lack of evidence reports to show the efficacy of using webinar data as observation data 
to add values to the research (Testers et al., 2015). In the author's opinion, a webinar that allows two-way communication between the host and audiences could be an ideal observational qualitative data source. This method enables the observation of presenters' facial expression as well as the collection of additional data through the 'Question and Answer (Q\&A)' session at the end of the hosted webinar. In terms of popularity, Google Trend statistics have shown a whopping increase of 'Webinar' search item by 257.90\% from March 2020 to July 2020. Concurrently, Zoom has recorded an increase of 169\% in its Quarter 2 in 2020's revenue as the remote work trend continues $(\mathrm{Yu}, 2020)$.

Despite webinars' great uses, there are no articles that address qualitative research methodology via webinar to date. The use of webinars has been discussed as a useful tool for training, learning, and teaching purposes (Gegenfurtner \& Ebner, 2019; Wang \& Hsu, 2008). The empirical research examining webinars in training contexts, human resource development and adult education remains scarce (Gegenfurtner et al., 2020). No study has addressed the use of webinar as a tool for data collection. This paper's results could enrich the data and provide additional data to verify the qualitative findings from the Digital Banking Study published previously (Tiong, 2020). Through interpretive research philosophy, this paper discusses the potential use of webinars, including the preparation, challenges, advantages, disadvantages, and limitations of the webinar as a qualitative data collection tool based on the real-time experience during the conduct of the Digital Banking Study. As it is a relatively new technique to be mastered, it is necessary to understand this new methodology's process and design that could help today's researchers conduct useful qualitative data collection from webinars' widespread use. This paper will comprehend the benefits of obtaining qualitative data from webinars and expand the knowledge on sample collection methodology amidst the unprecedented pandemic challenges such as social distancing and wearing masks, which hinders face-to-face interaction in qualitative data collection. The findings could contribute to the knowledge that appeals to target segments such as educators, postgraduates, academic researchers, or business analysts, who intend to use this method to obtain data qualitatively.

\section{Literature Review}

\section{The Digital Banking Study}

As part of the digital transformation plan, the Central Bank of Malaysia (also known as Bank Negara Malaysia) has sketched the procedure to issue up to five digital banking licenses for the eligible operator to set up the first virtual bank in Malaysia. Little do we know the factors could influence potential Malaysian users to accept or reject this service before it becomes a reality. Hence, it prompts us to study the possible factors influencing users' perception of adopting digital banking services under the Digital Banking Study. The Digital Banking Study uses a conceptual research model developed based on TAM theories integrated with the IDT model (Figure 1).

TAM theories are commonly applied to study consumer attitudes and behaviors toward new technology adoption through understanding the impact of perceived ease of use and perceived usefulness (Marangunić \& Granić, 2015), and social influence (K. J. Patel \& Patel, 2018). Extended TAM was applied to study the acceptance of mobile payments (Dahlberg et al., 2003), online shopping (Gefen et al., 2003; Tong, 2010), mobile instant messaging (Jiang \& Deng, 2011), e-commerce, and mobile commerce (Pavlou, 2003; Wei et al., 2009). Meanwhile, IDT explains how users adapt technological advances with five conceptually different factors that could influence the potential adopters' attitudes and intentions during the adoption process: relative advantage, complexity, compatibility, trialability, and observability (Rogers, 1995). The IDT has been used to predict customers' usage intention toward mobile payment adoption among Taiwanese consumers (Yeh, 2020), mobile banking adoption among the Indians (Dash et al., 2014) and Saudi Arabians (Al-Jabri \& Sohail, 2012); as well as the adoption of internet banking services in Greece (Giovanis et al., 2012), Malaysia (Nor \& Pearson, 2008) and rural South Africa (Ramavhona \& Mokwena, 2016). 


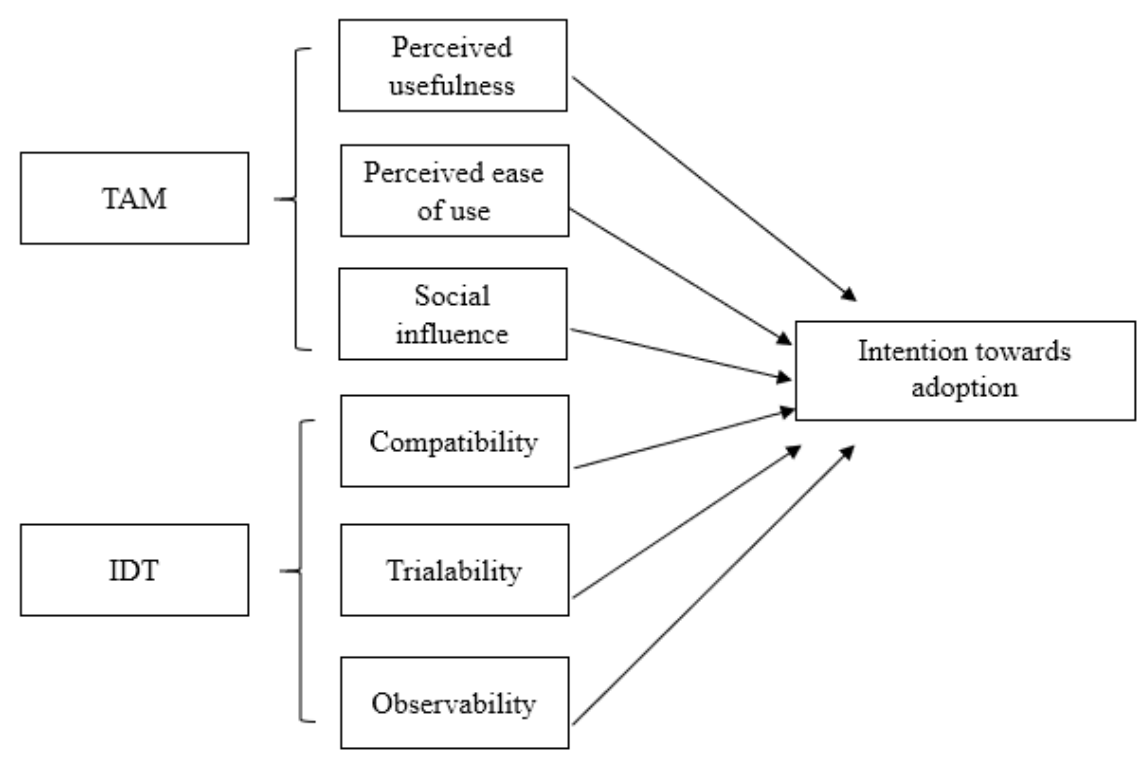

Figure 1 - Conceptual Framework proposed in the Digital Banking Study

Digital banking services and its development in Malaysia are actively discussed among industry players due to its potential for profit and revenue growth and the uncertainties that could be faced by the consumers and digital bank licensee contenders. Based on a business perspective, it would be vital to examine the steps taken by Malaysian banks, fintech, and start-ups in response to the country's competitive digital banking landscape and address the market demand that remains or capture the market. Nevertheless, focusing on the consumer perspective could provide information on the mechanism for potential users in respond to digital banking service in the current change in the digital technology and digital banking landscape in Malaysia. Both perspectives from industry players and consumers provide insight that could help identify a suitable marketing strategy and find the digital banking service or product's marketing edge.

\section{Webinars for Education}

Webinar is defined as a digital platform that combines web and seminar, which offers two-way communication for interactions and collaborations between hosts and participants across the world wide web (Verma \& Singh, 2010). It is originated from the Computer-Mediated Communication (CMC) systems that can be synchronous (real-time) or asynchronous (delayed time) communication (Romiszowski \& Mason, 1996; Wang \& Hsu, 2008). $\mathrm{CMC}$ system has been an essential support to online learning. Its ability to transmit video, audio, and images enables users to share and exchange information in a real-time and two-way format (Kerr \& Hiltz, 1982). Thus, webinar creates opportunities for educators and learners to experience different online interaction levels (Wang \& Hsu, 2008).

Although practical webinar-session guidelines are useful for instruction to use webinars for education, educators and trainers need literatures that emphasizes research and examines the selection of appropriate webinar-related pedagogies (Anderson et al., 2006). The previous study has also suggested that teaching staff enthusiasm alone is insufficient to promote and integrate digital tools such as mobile technology within the teaching and learning sphere (Salavati, 2016). Another study also posits the importance of focus on pedagogy and its relevance in digital technology used to build digital confidence (Greener \& Wakefield, 2015). A qualitative research was conducted to investigate pedagogical issues underlying the webinar tool in online learning and training which 
discovered four chief techniques that are observation, open-ended survey, focus group and recorded webinar training sessions. The study has also shown the utilization of qualitative methods in examining the webinar's role as a two-way synchronous digital tool in online learning (Wang \& Hsu, 2008).

Additionally, various discussions on the use of webinar as digital tool in educating medical trainees, such as on Core Surgical Training (CST) selection, provision of support and preparation for plastic surgery examination, and to deliver lectures to improve learning experiences of medical residents in the U.K. (Mayorga et al., 2014; N. M. Patel et al., 2020; Reissis et al., 2020). Furthermore, the use of webinar as the marketing and sales tool in internet marketing can manifest in knowledge sharing and demonstrations, further stimulate interactivity, personalization, and engagement with customers (Voskamp, 2012), as well as a useful educational tool to address management and industry issues related to equestrian practice (Pulec et al., 2016). Despite the abundant use of webinars in teaching, empirical research examining webinars in training contexts, human resource development, and adult education remains scarce (Gegenfurtner et al., 2020).

\section{Triangulation}

There are many unfamiliar consumers of digital banking services in Malaysia. New innovations are often rejected or resisted as users are not aware of the potential benefits or risks (Kleijnen et al., 2009). It requires more research and discussion in view that digital bank services' development is still at the infancy stage. The purpose of using a webinar as a data collection tool is based on the use of the triangulation method, where it is believed to be a credible and useful method of researching to improve both the quality and quantity of gathered data, enhances the validity and reliability of the research by overcoming potential bias, error vulnerability, and skepticisms resulting from the use of the single method or single source of data in a study (Begley, 1996). There are several types of triangulation, namely: 'Theory or Perspective Triangulation' such as the use of multiple perspectives to interpret data, 'Triangulation of Sources' which is the use of different sources within the same method, 'Methods Triangulation' that represents the use of different data collection method, and 'Analyst Triangulation' such as the use of further analysis to review data (Patton, 1990). Likewise, triangulation is advocated as a strategy to achieve a more comprehensive understanding of phenomena using multiple measures to capture the study's construct (Lambert \& Loiselle, 2008). By using the triangulation method, we can understand the perception on the consumer's behavior intention towards the adoption of digital banking services from the group of experts such as bankers, fintech entrants, and monetary policy bankers where their opinions have been actively discussed through non-academic researches including news articles, experts' interviews, and webinars.

\section{Observation data}

Qualitative research can contribute to the reliability of findings and enriches data to conceptualize the phenomenon (Lambert \& Loiselle, 2008). Additionally, qualitative data can also be collected in verbally or written texts and visual images associated primarily with research strategies such as case studies, grounded theory, ethnography and phenomenology, and research methods such as interviews, documents, and observation (Denscombe, 2010). Qualitative data can also be obtained through observation, which is defined as 'the systematic description of events, behaviors, and artifacts in the social setting chosen for the study.' We proposed that webinar can be a platform to collect observation data that include the fieldwork descriptions of activities, behaviors, actions, conversations, interpersonal interactions, organizational or community processes, or any other aspect of observable human experience (Marshall \& Rossman, 2015). In a previous study, a blended approach of participant observation and video recording was used to enhance the validity of the researcher's interpretation of in-person words (Paterson et al., 2003). It is remarked that observation data derived from the qualitative method can contribute to the reliability of findings and enriches data to conceptualize the phenomenon (Lambert \& Loiselle, 2008). Therefore, this study has selected suitable webinars as the platform 
for observation data collection to increase the depth of data and allow us to generate more research data for Digital Banking Study.

\section{Methods}

\section{Study design}

This qualitative study was conducted as part of the Digital Banking Study to investigate the factors influencing the behavioral intention to adopt digital banking services among Malaysians. Interpretivist research philosophy was used throughout this paper to examine the potentials, advantages, and disadvantages of using webinars as a new source of the data collection method. Using interpretivism, we can conduct an in-depth investigation and qualitative research through webinars using a small sample size (Saunders et al., 2012). The study design is based on ethnography to study behaviors, perceptions, and social interactions that occur within a specific group, namely the expert in digital bank and finance (Reeves et al., 2008).

\section{Sampling and data collection}

The target sample population of this study is the experts who have experience in digital banking, technology, and finance. Purposive sampling method was adopted as this allows us to achieve an in-depth understanding of digital banking services and generate new knowledge through the processes of comparison and contrast with quantitative results (Palinkas et al., 2015; Patton, 2002). The selection of webinars was first started by identifying and selecting suitable webinar keywords on the internet: Malaysia, virtual bank, digital bank, fintech, challenges, and opportunities. The consistency of quantitative data collection was ensured by selecting webinars conducted from April to June 2020 that discuss the trend, opportunity, and challenges faced by Malaysian fintech players, banks, or start-ups in competing for Malaysia's first digital bank license. The appropriate selection was made by comparing to Digital Banking Study's research theme to ensure that the topics discussed will be relevant to conclude the factors influencing the adoption of digital banking services in Malaysia. A total of three webinars involving fintech players, journalists, and economists in the field of digital banking were selected as the observation points for this research purpose. Throughout the study, the experience during webinar data as appropriate research data was identified in a detailed journal.

\section{Setting and procedure}

The essential tools and documents for the recording and observations obtained from the webinar were identified following a suitable selection of related webinar sessions. To ensure the smooth and uninterrupted process of observing the selected webinar sessions, we also rectified relevant technical issues pertaining to computer and internet settings before webinar sessions. Relevant technical matters include the stability of the internet, functioning audio and speaker, and the video and audio recorder's effectiveness. The information obtained from the webinar sessions were then captured and recorded in an observation log prepared to document these experiences. Additionally, these webinars were recorded in two recording modes: video recordings that capture the speech and presentation explicitly and text recordings as typed by the researcher simultaneously throughout webinar sessions. The webinar session recordings were then replayed repeatedly to review the session details.

\section{Analysis}

The observation log and video recordings were analyzed to generate pattern codes, and the frequency of the words was identified using the Wordcloud software (Zygomatic, The Netherlands). The scripts placed from the webinars were recategorized into different topics based on the conceptual framework proposed in the Digital Banking Study, as shown in Figure 1. To enable us to identify the results' validity, we compared the webinar findings against the main findings collected from previously published quantitative results (Tiong, 2020). TAM and IDT theories were used as the point of reference for comparing the webinar's observation data against 
quantitative findings. Meanwhile, the potential of its uses as an effective qualitative data collection method was also discussed based on the researcher's experience during observation of webinar sessions and categorized according to advantages, limitations, and lessons to learn.

\section{Results and Discussion}

Three sessions of webinars involving nine experts in finance, digital banking technology, and fintech consultation fields were selected for in-depth understanding and comparison with the Digital Banking Study's objective, and the experience of collecting qualitative results using webinars was discussed. The experts were coded according to their background, as shown in Table 1.

Table 1 - Background of panel

\begin{tabular}{ll}
\hline Code & Background of panel \\
\hline W1-1 & CEO of leading mobile wallet service provider in Malaysia. \\
W1-2 & Co-founder of the challenger banking app in Malaysia. \\
W1-3 & General Manager for retail banking component of a fintech software service provider. \\
W1-4 & Partner of a multinational professional consulting firm. \\
W2-1 & CEO of leading payment service provider and merchant acquirer in the ASEAN region. \\
W2-2 & Managing director of Europe division of a global leading banking technology firm. \\
W2-3 & Strategy director of a leading technology-as-a-service platform for financial institutions in China region. \\
W3-1 & Head of innovation from United Nations entity. \\
W3-2 & Technical program manager specialized in mobile payment technology. \\
W1 refers to webinar 1, W2 refers to webinar 2, W3 refers to webinar 3. The panels did not include the moderators.
\end{tabular}

These experts have diverse backgrounds in fintech, banking, business consulting, and technology firms. Through webinars, researchers able to obtain different expert opinions regarding the challenges and opportunities of running digital banking services in Malaysia. The panels' scripts were reorganized according to pattern codes, and Wordcloud software was used to identify the frequency of words present in webinars discussions. The most frequent terms being mentioned during webinars was shown in Figure 2.

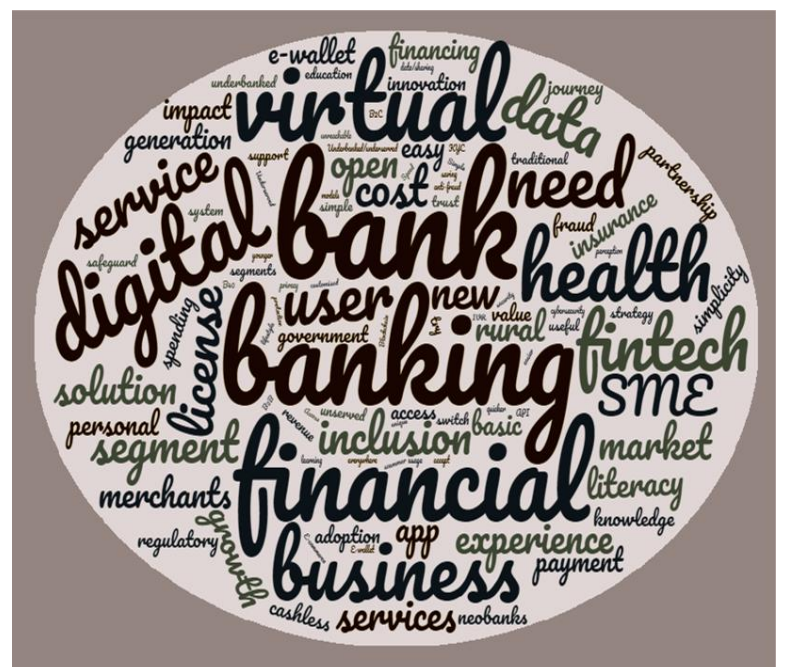

Figure 2 - Extraction of words according to frequency based on wordcloud

The Worldcloud showed the relevance of the expert's opinion regarding the digital banking services in Malaysia, where the most frequent words mentioned were: Bank, banking, financial, digital, virtual, financial, and business. The excerpts from the observation log compiled from three selected webinars were then recategorized according to TAM, and IDT theoretical perspectives for the comparison needs with qualitative data results. A 
summary of the findings is shown in Table 2 and Table 3 for TAM and IDT constructs. It is shown that a high consistency was observed from the selected webinars, therefore, proving the evidence that observation data from webinar sources can be used to validate quantitative results according to the research objectives of the Digital Banking Study.

Table 2 - Comparison of Qualitative and Quantitative Findings Based on TAM Constructs

\begin{tabular}{|c|c|c|}
\hline Construct & $\begin{array}{l}\text { Qualitative findings based on expert } \\
\text { opinion }\end{array}$ & $\begin{array}{l}\text { Quantitative findings based on user } \\
\text { perception }\end{array}$ \\
\hline $\begin{array}{l}\text { Perceived } \\
\text { ease of use }\end{array}$ & $\begin{array}{l}\text { Experts believed that users would prefer } \\
\text { products that offer: } \\
\text { - } \quad \text { simplicity, } \\
\text { - } \text { easily accessible, } \\
\text { - quickly learn the process, and } \\
\text { - functionally comfortable banking } \\
\quad \text { journey. }\end{array}$ & $\begin{array}{l}\text { Users perceived that digital banking service must } \\
\text { be: } \\
\text { - easy to use, } \\
\text { - easy to have the equipment to use, } \\
\text { - easy to learn how to operate, and } \\
\text { - not require much mental effort. }\end{array}$ \\
\hline $\begin{array}{l}\text { Perceived } \\
\text { usefulness }\end{array}$ & $\begin{array}{l}\text { Experts expressed that a useful digital bank } \\
\text { service is: } \\
\text { - able to serve different market } \\
\text { segments, with various kinds of } \\
\text { products, } \\
\text { - improve users' financial knowledge and } \\
\text { recommend better banking products } \\
\text { according to the user profile. }\end{array}$ & $\begin{array}{l}\text { Users perceived that digital banking service must } \\
\text { be useful in terms of: } \\
\text { - accessible anywhere and convenient to } \\
\text { use, } \\
\text { - the use will increase user productivity, } \\
\text { the use allows users to enjoy more } \\
\text { savings or investment returns than other } \\
\text { means of banking. }\end{array}$ \\
\hline $\begin{array}{l}\text { Perceived } \\
\text { social } \\
\text { influence }\end{array}$ & $\begin{array}{l}\text { Experts expressed that social influence could } \\
\text { convince one's intention to adopt digital } \\
\text { banking services through: } \\
\text { - peer pressure when the product is } \\
\text { excellent, and } \\
\text { - the younger generation is likely to be } \\
\text { influenced psychologically or follow } \\
\text { older generation suits that generally } \\
\text { served as role models. }\end{array}$ & $\begin{array}{l}\text { Users agreed that social influence plays in the part } \\
\text { of influencing their intention to adopt digital } \\
\text { banking services, mainly from: } \\
\text { - people who control their behavior, } \\
\text { - people who are important to them, and } \\
\text { - the self-belief that many people will use } \\
\text { digital banking services. }\end{array}$ \\
\hline \multicolumn{3}{|c|}{ Table 3 - Comparison of Qualitative and Quantitative Findings Based on IDT Constructs } \\
\hline Construct & $\begin{array}{l}\text { Qualitative findings based on expert } \\
\text { opinion }\end{array}$ & $\begin{array}{l}\text { Quantitative findings based on user } \\
\text { perception }\end{array}$ \\
\hline Compatibility & $\begin{array}{l}\text { Experts believed that it is essential for a digital } \\
\text { banking service provider to design a product } \\
\text { that is compatible with users by: } \\
\text { - knowing what consumer want through } \\
\text { understanding, and } \\
\text { - linking their lifestyle to banking needs. }\end{array}$ & $\begin{array}{l}\text { Users believed that compatibility influences their } \\
\text { intention to use digital banking services when: } \\
\text { - the service fits their lifestyle and needs, } \\
\text { and } \\
\text { - the service will be compatible with their } \\
\text { banking needs }\end{array}$ \\
\hline Trialability & $\begin{array}{l}\text { Experts agreed that education and training are } \\
\text { vital to help people to understand and adopt } \\
\text { digital bank. }\end{array}$ & $\begin{array}{l}\text { Users perceived that they could be convinced to } \\
\text { use digital banking services to run the trial } \\
\text { version. }\end{array}$ \\
\hline Observability & $\begin{array}{l}\text { Experts commented that the COVID-19 } \\
\text { pandemic that led to the whole country's } \\
\text { lockdown had accelerated Malaysian openness }\end{array}$ & $\begin{array}{l}\text { Users agreed that they would adopt digital } \\
\text { banking services if they able to observe: } \\
\text { - the benefits of their users quickly, and }\end{array}$ \\
\hline
\end{tabular}


to digital banking innovation. They observed the benefits of fintech products, including

- how they are being used.

digital bank service.

Based on our real experiences, we studied the credibility and validity of the qualitative data collected from the webinar by comparing the results with quantitative data of the Digital Banking Study's empirical analysis. The result shows that qualitative data from webinars based on experts' opinions is relevant to similar constructs in the prediction of factors influencing users' behavioral intention to adopt digital banking services, thus adding more research verification discussion rooms. Nonetheless, this paper's focus also needs to highlight our real experience of using a webinar as the new qualitative method to collect useful data. Therefore, both the advantages and disadvantages of the process are evaluated when assessing the webinar's effectiveness as a source of data collection. The advantages and disadvantages of webinar use as a source of qualitative data were summarized in Table 4.

A diverse, rich, and concise data can be obtained as the researchers are granted access to presenters from various professional groups' keynotes and insights despite being conducted remotely. The convenience of remote webinars posed as an advantage for the researchers. The effects of globalization, particularly with the growth of information society and advancement of society's development, conducting physical seminars may phase out with the rising trend of webinars in remote communication, working and convenient access with its costs, time, logistics and resource efficient advantages. Moreover, recorded webinar data also allows researchers to facilitate data verification easily.

Table 4 - Advantages and disadvantages of using a webinar as a source of data collection

Advantages Disadvantages

Convenient

- Not location bound.

- Able to refer to the recorded webinar for verification.

- Others organize no extra effort in coordination as a webinar.

Cost-Efficient

- No setup fees are required.

- No travel cost is required.

- No additional cost to invite experts for opinions.

Time Efficient

- No travel is required.

- Less time required to collect data as compared to self-arrangement setup interview or observation scene.

Sample diversity

- Expands into regional locations for research.

- Facilitates inclusions of a broader range of groups for opinions or participation.
Sample bias

- Presenters' views may not be relevant to the research topic.

- Presenters' background is mainly successful and affluent, may not represent the vast opinion of most people.

Potential technology failure that affects data quality

- Computer failure/faulty.

- Poor internet connectivity.

- The potential loss of silence from presenters due to technical issues.

Lack of control

- Not all webinars will fit the research theme.

- More time and effort may be required to dissect the captured data based on their research theme.

Lack of comprehensive data

- The presenters' facial expressions may not be captured, especially when presenters' videos are not available.

- Questions asked during the Q\&A session may not be answered. 
A list of practical recommendations for future users of this data collection method is presented in Table 5. These recommendations are derived from first-time experience employing webinars as a qualitative data collection tool. Webinars can contribute to additional data to enrich the research finding; thus, it is crucial to identify essential keywords in the selection of practical webinar sessions relevant to the research objective as the screening and selection process to determine the ideal webinar can be time-consuming. Nonetheless, it is also recommended to select at least three webinar sessions with diverse presenters' backgrounds to further enhance data collection. However, the chosen webinar sessions must not be held concurrently and should be held at a reasonable gap of time to enable researcher sufficient time for essential preparation and participation. The use of video recorder software is an added advantage for the researcher to playback webinar session recordings as reference and data verification.

Table 5 - Recommendations to elicit quality data from the webinar

\begin{tabular}{ll}
\hline Item & Recommendations \\
\hline Selection & $\begin{array}{l}\text { Identify the keywords that meet the research objective for the easy selection of suitable webinar } \\
\text { sessions. }\end{array}$ \\
$\begin{array}{l}\text { Tools } \\
\text { Organization of video recorder software to record the webinar session for data verification. }\end{array}$ & $\begin{array}{l}\text { Organize the webinar data onto Microsoft word according to the presenter's background or } \\
\text { research theme. }\end{array}$ \\
Analysis & $\begin{array}{l}\text { Make use of Wordcloud software to identify the words that appear most frequently and analyze the } \\
\text { data according to the research objective or theme. }\end{array}$
\end{tabular}

\section{Discussion}

Although conducting a quality face-to-face interview and participant observation is extensively discussed in the literature (Fritz \& Vandermause, 2018), however, there is insufficient reports or research on webinar use for qualitative data collection. The employment of webinars is a relatively new data collection method; thus, it is necessary to discuss the advantages and disadvantages of conducting a useful webinar data collection.

This paper is the first in the academic industry to discuss webinars' potential use as a new tool of qualitative data collection that would contribute a unique perspective and knowledge on the type of research tool used to collect an in-depth data. The qualitative data collected for the Digital Banking Study also contributes to the new experience that will be beneficial to the business and management field, especially in the finance industry such as banks and fintech, consumers, policymakers. The findings of this study will also be beneficial to future researchers in understanding the factors influencing the adoption of digital banking services. This study has also shown that webinar-based qualitative data analysis of Digital Banking Study's theories could manifest consumer perception from a socio-psychological perception in the innovation and its adoption in today's digital transformation era based on the observation obtained from expert's opinion. Based on the extracted scripts according to the experts, the observation log identified the importance of factors such as ease of use, usefulness, social influence, compatibility, trialability, security, and privacy data management that will determine the success of digital bank in Malaysia and help to penetrate market across different types of users, generations and geographical locations. This is consistent with the quantitative results which further convinced the researchers that the conceptual framework from the theoretical perspectives of both TAM and IDT could explain potential user's behavioral intention in the adoption of digital banking services (Tiong, 2020). Furthermore, the employment of triangulation method, particularly data collection from webinars as a source of the qualitative approach, has further enhanced the research data which was intended to be answered by the Digital Banking Study. Most importantly, the webinar's use has undoubtedly created an opportunity for researchers to conduct study amidst the travel restriction imposed during the pandemic of COVID-19. 
Data collection plays a significant role in any type of research study; thus, data collection method is particularly important as this impact the results of the study. Therefore, it is imperative that researchers control data collection method to obtain accurate data for analysis and generate significant research findings. We proposed that the mass data and scripts obtained from the webinar sessions can be easily analyzed by using Wordcloud software to identify the most repeated words. The categorization of data is followed according to research objectives or the presenter's background. For instance, in this study, we have referred to the conceptual framework proposed in the Digital Banking Study. According to TAM and IDT constructs, the organization of data allowed us to compare the conceptual framework, followed by a comparison with an existing literature review to explore and generate new findings.

Nonetheless, the use of webinar data can be limited by sample bias and potential technology failure. Additionally, the views may not be relevant to the researcher's research objectives or represent common opinion despite a diverse perspective of presenters to enrich the data. The researchers' lack of control also means more time and effort will be needed to find relevant webinars or segregate the contents suited to the research objective. Moreover, lack of comprehensive data can occur due to potential technology failure during live webinar sessions. Additionally, as aforementioned, the observation technique particularly one's facial expression is essential in qualitative data observation, likewise a lack of facial expression from the session can affect the results of the study.

Although this study has shown the advantages, disadvantages, and limitations of using a webinar as a qualitative method, many gray areas are worth exploring in future studies. A larger sample size, more empirical analysis, or experience from different research fields can contribute more convincing data on webinars' potential use as an effective qualitative research method. Moreover, the current study does not discuss researchers' experience of coordinating or moderating webinar sessions. It is purely researchers' observatory experience on webinars coordinated by others; thus, these experiences may not be accurate or relevant for future researchers who wish to host or moderate webinar sessions for data collection purposes. Nonetheless, this study's discussions open an opportunity to assess webinars' potential use in qualitative research. The findings of this study can be considered for future exploration of webinars' adoption as a new tool for data collection among academics, researchers, and the public.

\section{Conclusion}

This paper has established several conclusive discussions on the potential use of webinars, which may lead to improved data quality and provide useful tips and guides for future researchers in the employment of webinars as a qualitative data collection tool. This study's practical implication has shown that webinar is a useful data collection tool in the absence of face-to-face and physical participant observation. Moreover, it is also an alternative of data sourcing method that enables a wider scope of research sampling and area and access to experts' opinion and collaboration via high-speed internet connectivity. As globalization continues, so does the rapid development of technology, which drives the abundance and confident use of digital tools for education (Amhag et al., 2019; Greener \& Wakefield, 2015). Therefore, the rising use of webinars and video conferencing software, especially in the current pandemic situation, has opened new opportunities for researchers to explore new data collection methods despite the challenges and limitations of social distancing and physical movement.

Funding: This research received no external funding.

Acknowledgments: The authors would like to express their sincere gratitude to research participants as well as the guidance from Mr. Haritharan Devanthran from SEGi College Sarawak, Kuching, Malaysia.

Conflicts of Interest: The authors declare no conflict of interest. 


\section{References}

Al-Jabri, brahim M., \& Sohail, M. S. (2012). Mobile banking adoption: Application of diffusion of innovation theory. Journal of Electronic Commerce Research, 13(4), 379-391.

Amhag, L., Hellström, L., \& Stigmar, M. (2019). Teacher Educators' Use of Digital Tools and Needs for Digital Competence in Higher Education. Journal of Digital Learning in Teacher Education, 35(4), 203-220. https://doi.org/10.1080/21532974.2019.1646169

Anderson, L., Fyvie, B., Koritko, B., McCarthy, K., Paz, S. M., Rizzuto, M., Tremblay, R., \& Sawyers, U. (2006). Technical evaluation report 54. Best practices in synchronous conferencing moderation.

International Review of Research in Open and Distance Learning, 7(1), 93-98. https://doi.org/10.19173/irrodl.v7i1.308

Begley, C. M. (1996). Triangulation of communication skills in qualitative research instruments. Journal of Advanced Nursing, 24(4), 688-693. https://doi.org/10.1046/j.1365-2648.1996.02446.x

Carnevale, J. B., \& Hatak, I. (2020). Employee adjustment and well-being in the era of COVID-19: Implications for human resource management. Journal of Business Research, 116, 183-187. https://doi.org/10.1016/j.jbusres.2020.05.037

Dahlberg, T., Mallat, N., \& Öörni, A. (2003). Trust enhanced technology acceptance model - consumer acceptance of mobile payment solutions. Stockholm Mobility Roundtable, January 2003, 22-23.

Dash, M., Bhusan, P. B., \& Samal, S. (2014). Determinants of Customers' Adoption of Mobile Banking: An Empirical Study by Integrating Diffusion of Innovation with Attitude. Journal of Internet Banking and Commerce, 19(3).

Davis, F. D. A. (1986). Technology Acceptance Model for Empirically Testing New End-User Information Systems: Theory and Results (Doctoral dissertation, Massachusetts Institute of Technology).

Denscombe, M. (2010). The Good Research Guide: For Small-scale Social Research Projects. McGraw-Hill Education (UK).

Donthu, N., \& Gustafsson, A. (2020). Effects of COVID-19 on business and research. Journal of Business Research, 117, 284-289. https://doi.org/10.1016/j.jbusres.2020.06.008

Fritz, R. L., \& Vandermause, R. (2018). Data Collection via In-Depth Email Interviewing: Lessons From the Field. Qualitative Health Research, 28(10), 1640-1649. https://doi.org/10.1177/1049732316689067

Gefen, D., Karahanna, E., \& Straub, D. W. (2003). Trust and TAM in online shopping: An integrated model (Vol. 27, Issue 1). https://doi.org/https://doi.org/10.2307/30036519

Gegenfurtner, A., \& Ebner, C. (2019). Webinars in higher education and professional training: A metaanalysis and systematic review of randomized controlled trials. Educational Research Review, 28. https://doi.org/10.1016/j.edurev.2019.100293

Gegenfurtner, A., Zitt, A., \& Ebner, C. (2020). Evaluating webinar-based training: a mixed methods study of trainee reactions toward digital web conferencing. International Journal of Training and Development, 24(1). https://doi.org/10.1111/ijtd.12167

Giovanis, A. N., Binioris, S., \& Polychronopoulos, G. (2012). An extension of TAM model with IDT and security/privacy risk in the adoption of internet banking services in Greece. EuroMed Journal of Business, 7(1), 24-53. https://doi.org/10.1108/14502191211225365

Greener, S. L. , \& Wakefield, C. (2015). Developing confidence in the use of digital tools in teaching. Electronic Journal of E-Learning, 13(4), 260-267. 
Jiang, G., \& Deng, W. (2011). An empirical analysis of factors influencing the adoption of Mobile Instant Messaging in China. International Journal of Mobile Communications, 9(6), 563-583. https://doi.org/10.1504/IJMC.2011.042777

Kapasia, N., Paul, P., Roy, A., Saha, J., Zaveri, A., Mallick, R., Barman, B., Das, P., \& Chouhan, P. (2020). Impact of lockdown on learning status of undergraduate and postgraduate students during COVID-19 pandemic in West Bengal, India. Children and Youth Services Review, 116. https://doi.org/10.1016/j.childyouth.2020.105194

Kerr, E. B., \& Hiltz, S. R. (1982). Computer-Mediated Communication Systems: Status and Evaluation. Academic Press.

Kleijnen, M., Lee, N., \& Wetzels, M. (2009). An exploration of consumer resistance to innovation and its antecedents. Journal of Economic Psychology, 30(3), 344-357. https://doi.org/10.1016/j.joep.2009.02.004

Lambert, S. D., \& Loiselle, C. G. (2008). Combining individual interviews and focus groups to enhance data richness. Journal of Advanced Nursing, 62(2). https://doi.org/10.1111/j.1365-2648.2007.04559.x

Marangunić, N., \& Granić, A. (2015). Technology acceptance model: a literature review from 1986 to 2013. Universal Access in the Information Society, 14(1). https://doi.org/10.1007/s10209-014-0348-1

Marshall, C., \& Rossman, G. B. (2015). Designing Qualitative Research | (6th ed.). SAGE Publications Inc.

Mayorga, E. P., Bekerman, J. G., \& Palis, A. G. (2014). Webinar software: A tool for developing more effective lectures (online or in-person). Middle East African Journal of Ophthalmology, 21(2), 123-127. https://doi.org/10.4103/0974-9233.129756

Nor, K. M., \& Pearson, J. M. (2008). An Exploratory Study Into The Adoption of Internet Banking in a Developing Country: Malaysia. Journal of Internet Commerce, 7(1). https://doi.org/10.1080/15332860802004162

Palinkas, L. A., Horwitz, S. M., Green, C. A., Wisdom, J. P., Duan, N., \& Hoagwood, K. (2015). Purposeful Sampling for Qualitative Data Collection and Analysis in Mixed Method Implementation Research. Administration and Policy in Mental Health and Mental Health Services Research, 42(5). https://doi.org/10.1007/s10488-013-0528-y

Papadopoulos, T., Baltas, K. N., \& Balta, M. E. (2020). The use of digital technologies by small and medium enterprises during COVID-19: Implications for theory and practice. International Journal of Information Management, June, 102192. https://doi.org/10.1016/j.ijinfomgt.2020.102192

Patel, K. J., \& Patel, H. J. (2018). Adoption of internet banking services in Gujarat. International Journal of Bank Marketing, 36(1). https://doi.org/10.1108/IJBM-08-2016-0104

Patel, N. M., Khajuria, A., \& Khajuria, A. (2020). Utility of a webinar to educate trainees on UK core surgical training (CST) selection - A cross sectional study and future implications amidst the COVID-19 pandemic. Annals of Medicine and Surgery, 59(September), 35-40. https://doi.org/10.1016/j.amsu.2020.08.054

Paterson, B. L., Bottorff, J. L., \& Hewat, R. (2003). Blending Observational Methods : Possibilities, Strategies, and Challenges. 29-38. https://doi.org/10.1177/160940690300200103

Patton, M. Q. (1990). Enhancing the Quality and Credibility of Qualitative Analysis. Health Services Research, 34(5 Pt 2), 1189-1208.

Patton, M. Q. (2002). Qualitative research and evaluation methods (3rd ed.). Sage Publications.

Pavlou, P. A. (2003). Consumer acceptance of electronic commerce: Integrating trust and risk with the technology acceptance model. International Journal of Electronic Commerce, 7(3), 101-134. https://doi.org/10.1080/10864415.2003.11044275 
Prime Minister's Office of Malaysia. (2020, March 16). The Prime Minister's Special Message on COVID-19 - 16 March 2020. Prime Minister's Office of Malaysia. https://www.pmo.gov.my/2020/03/perutusan-khasyab-perdana-menteri-mengenai-covid-19-16-mac-2020/

Pulec, K. E., Skelly, C. D., Brady, C. M., Greene, E. A., \& Anderson, K. P. (2016). Effectiveness of webinars as educational tools to address horse industry issues. Journal of Extension, 54(3), undefined.

Ramavhona, T. C., \& Mokwena, S. (2016). Factors influencing Internet banking adoption in South African rural areas. South African Journal of Information Management, 18(2), 642.

https://doi.org/10.4102/sajim.v18i2.642

Reeves, S., Kuper, A., \& Hodges, B. D. (2008). Qualitative research methodologies: ethnography. BMJ, 337(a1020). https://doi.org/10.1136/bmj.a1020

Reissis, D., Joji, N., Campbell, E., Sharma, V. P., Staruch, R. M. T., \& Baker, B. G. (2020). PLASTA National Webinar Series: A developing model for remote surgical education. In Journal of Plastic, Reconstructive and Aesthetic Surgery (Vol. 73, Issue 8, pp. 1575-1592). Churchill Livingstone.

https://doi.org/10.1016/j.bjps.2020.05.008

Rogers, E. M. (1995). Diffusion of Innovations (4th ed.). New York: Free Press.

Romiszowski, A., \& Mason, R. (1996). Computer-mediated communication. Handbook of Research for Educational Communications and Technology, 2, 397-431.

Salavati, S. (2016). Use of Digital Technologies in Education: The Complexity of Teachers' Everyday Practice (Doctoral dissertation, Linnaeus University Press).

Saunders, M., Lewis, P., \& Thornhill, A. (2012). Research Methods for Business Students (6th ed.). Pearson Education Limited.

Testers, L., Gegenfurtner, A., \& Brand-Gruwel, S. (2015). Motivation to transfer learning to multiple contexts. He School Library Rocks: Living It, Learning It, Loving It, June, 473-487.

Tiong, W. N. (2020). Factors Influencing Behavioural Intention towards Adoption of Digital Banking Services in Malaysia. International Journal of Asian Social Science, 10(8), 450-457.

https://doi.org/10.18488/journal.1.2020.108.450.457

Tong, X. (2010). A cross-national investigation of an extended technology acceptance model in the online shopping context. International Journal of Retail \& Distribution Management, 38(10), 742-759. https://doi.org/10.1108/09590551011076524

United Nations. (2020). Policy Brief: Education during COVID-19 and beyond. In United Nations. https://www.un.org/development/desa/dspd/wpcontent/uploads/sites/22/2020/08/sg_policy_brief_covid-19_and_education_august_2020.pdf

Venkatesh, V., \& Bala, H. (2008). Technology Acceptance Model 3 and a Research Agenda on Interventions. Decision Sciences, 39(2). https://doi.org/10.1111/j.1540-5915.2008.00192.x

Verma, A., \& Singh, A. (2010). Webinar - Education through digital collaboration. Journal of Emerging Technologies in Web Intelligence, 2(2), 131-136. https:/ / doi.org/10.4304/jetwi.2.2.131-136

Voskamp, M. L. (2012). Webinars as an effective marketing and sales tool in internet marketing (Master's thesis, University of Twente).

Wang, S. K., \& Hsu, H. Y. (2008). Use of the webinar tool (elluminate) to support training: The effects of webinar-learning implementation from student-trainers' perspective. Journal of Interactive Online Learning, 7(3), 175-194.

Webster, P. (2020). Virtual health care in the era of COVID-19. The Lancet, 395(10231), 1180-1181. https://doi.org/10.1016/s0140-6736(20)30818-7 
Wei, T. T., Marthandan, G., Chong, A. Y. L., Ooi, K. B., \& Arumugam, S. (2009). What drives Malaysian mcommerce adoption? An empirical analysis. Industrial Management and Data Systems, 109(3), 370-388. https:/ / doi.org/10.1108/02635570910939399

World Health Organization. (2020, March 11). WHO Director-General's opening remarks at the media briefing on COVID-19 - 11 March 2020. World Health Organization. https://www.who.int/directorgeneral/speeches/detail/who-director-general-s-opening-remarks-at-the-media-briefing-on-covid-19--11-march-2020

Xiong, S. (2013, November). Adoption of mobile banking model based on perceived value and trust. 2013 6th International Conference on Information Management, Innovation Management and Industrial Engineering. https://doi.org/10.1109/ICIII.2013.6703015

Yeh, H. (2020). Factors in the Ecosystem of Mobile payment affecting its use: From the customers' Perspective in Taiwan. Journal of Theoretical and Applied Electronic Commerce Research, 15(1), 13-29. https://doi.org/10.4067/S0718-18762020000100103

Yu, Y. (2020, June 3). Zoom's Q2 revenue jumps 169\% as remote work trend continues. Nikkei Asia. https://asia.nikkei.com/Business/Technology/Zoom-s-Q2-revenue-jumps-169-as-remote-work-trendcontinues.

Zhang, T. , L. C. , K. M. (2018). Banking “On-the-Go”: Examining Consumers' Adoption of Mobile Banking Services. Int. J. Qual. Serv. Sci. , 10, 279-295. https://doi.org/https://doi.org/10.1108/IJQSS-07-20170067 